conditioned by non-random events; the condition is influenced by emotional and environmental factors; there is a high placebo response; and the common yardstick of the number of tablets of glyceryl trinitrate consumed is open to many undefined individual errors. For these reasons the methods used in these studies, which were designed to correlate symptoms with electrocardiographic and relevant haemodynamic measurements, form a useful investigative model for the assessment and comparison of effectiveness of treatment in exerciseinduced angina pectoris both in the individual patient and in field studies.

We wish to thank the many physicians and surgeons who referred patients to us; Sisters F. Ellis and R. Cox and the nursing staff of the medical professorial unit, the General Infirmary, Leeds, for their help and co-operation; Mr. R. Stafford and the technicians of the cardiovascular unit without whose valuable help this work would not have been possible; the catheter room nurses who afforded such essential help; Dr. H. W. Peers, of the department of statistics, University of Leeds, for advice and help with the statistical design of the study and analysis of the results; Sir Ronald Tunbridge and Professor R. J. Linden for their help and encouragement throughout. B.S. is a Senior Ciba Research Fellow, M.C.G. is an Imperial Chemical Industries Research Fellow. tion.

This work was assisted by a grant from the Wellcome Founda-

Requests for reprints should be addressed to Dr. S. H. Taylor, Department of Medicine, the General Infirmary, Leeds LS1 3EX.

\section{References}

Astrom, H. (1968). British Heart fournal, 30, 44.

Biörck, G., Eliasch, H., Pernow, B., and Rosén, A. (1968). Acta Medica Scandinavica, 184, 275.

Chamberlain, D. A. (1966). American fournal of Cardiology, 18, 321.

Cohn, A. E., and Steele, J. M. (1935). American fournal of Physiology,

Dwyer, E. M., jun., Wiener, L., and Cox, J. W. (1968). Circulation, 38,

Evans, C. L. (1917). Fournal of Physiology, 51, 91. Fisher, R. A. (1946). Stastistical Methods for Research Workers. Edinburgh,
Oliver and Boyd.

Folle, L. E., and Aviado, D. M. (1965). Fournal of Pharmacology and Experimental Therapy, 149, 79.

Furberg, C. (1967). Acta Medica Scandinavica, 181, 21.

Gander, M., Veragut, U., Kohler, R., and Luhty, E. (1966). Cardiologia, $49,17$.

Gianelly, R. E., Treister, B. L., and Harrison, D. C. (1969). American fournal of Cardiology, 24, 161 .

Klocke, F. J., Kaiser, G. A., Ross, J., jun., and Braunwald, E. (1965). Circulation Research, 16, 376.

McKenna, D. H., et al. (1966). Circulation Research, 19, 520

Majid, P. A., Benaim, M., and Taylor, S. H. (1971). British fournal of Pharmacology, In press.

Majid, P. A., Sharma, B., Saxton, C., Stoker, J. B., and Taylor, S. H. (1970). Postgraduate Medical fournal, November Supplement, p. 67.

Prichard, B. N. C., Aellig, W. H., and Richardson, G. A. (1970). Postgraduate Medical fournal, November Supplement, p. 77.

Robinson, B. F. (1967). Circulation, 35, 1075.

Sarnoff, S. J., et al. (1958). American fournal of Physiology, 192, 148.

Sharma, B., Majid, P. A., Galvin, M. C., and Taylor, S. H. (1970). Postgraduate Medical fournal, November Supplement, p. 72.

Sharma, B., Majid, P. A., Meeran, M. K., and Taylor, S. H. (1971). British Heart fournal. In press.

Sharma, B., and Taylor, S. H. (1970). Lancet, 2, 902.

Sonnenblick, E. H., Braunwald, E., Williams, J. F., and Glick, G. (1965a). fournal of Clinical Investigation, 44, 2051

Sonnenblick, E. H., Ross, J., jun., Covell, J. W., Kaiser, G. A., and Braunwald, E. (1965b). American fournal of Physiology, 209, 919.

Stern, S., and Eisenberg, S. (1969). American Heart fournal, 77, 192

Taylor, S. H., MacDonald, H. R., Robinson, M. C., and Sapru, R. P. (1967). British Heart fournal, 29, 352 .

Taylor, S. H., Majid, P. A., and Sharma, B. (1970). Postgraduate Medical fournal, November Supplement, p. 57.

Taylor, S. H., and Sharma, B. (1971). British Heart Fournal. In press.

Whitsitt, L. S., and Lucchesi, B. R. (1967). Circulation Research, 31, 305.

\title{
In-vitro Inhibition of Leucocyte Migration in Crohn's Disease by a Sarcoid Spleen Suspension
}

\author{
J. M. T. WILLOUGHBY, D. N. MITCHELL
}

\section{British Medical fournal, 1971, 3, 155-157}

\section{Summary}

A Kveim suspension has been shown to inhibit the migration of leucocytes in vitro from 12 out of 18 patients with Crohn's disease but to have no comparable effect on leucocytes from patients with ulcerative colitis or from a group of patients with other diseases. These findings provide further evidence of cross-reactivity or of a possible aetiological link between Crohn's disease and sarcoidosis and suggest a further immunological distinction between Crohn's disease and ulcerative colitis.

\footnotetext{
Departments of Gastroenterology and Experimental Pathology, St. Bartholomew's Hospital, London E.C.1

J. M. T. WILLOUGHBY, B.M., M.R.C.P., Research Associate and Honorary Lecturer in Medicine

M.R.C. Tuberculosis and Chest Diseases Unit, Brompton Hospital, London S.W.3

D. N. MITCHELL, M.D., Member of Scientific Staff
}

\begin{abstract}
Introduction
A positive Kveim reaction has in the past been regarded as highly specific for sarcoidosis (Siltzbach, 1967). However, in a recent study Kveim tests were made with a carefully validated test suspension prepared from a sarcoid spleen (K12) in a series of 74 patients with definite or probable Crohn's disease (Mitchell, Cannon, Dyer, Hinson, and Willoughby, 1970). Microscopical readings of the biopsy specimens showed that $38(51 \%)$ had a positive Kveim test. Moreover, 12 out of 19 patients with clinically definite or histologically confirmed Crohn's disease had a positive reaction both to $\mathrm{K} 12$ and to another extensively validated test suspension (Hurley) prepared from a different sarcoid spleen.

The nature of the Kveim reaction is not understood, but it seems probable that it may represent a special class of reaction, possibly a "delayed, delayed-type" of cell-mediated cutaneous hypersensitivity response (Hart and Rees, 1967). Since the leucocyte migration test is of proved value as an in-vitro correlate of cell-mediated hypersensitivity (Søborg and Bendixen, 1967; Bendixen and Søborg, 1969) and had already been found to mediate a specific response to sarcoid spleen suspensions in sarcoidosis (Hardt and Wanstrup, 1969), it was decided to investigate the potential role of sarcoid and of normal spleen suspensions in the in-vitro inhibition of leucocytes in Crohn's disease, and to include for comparison similar tests in patients with ulcerative colitis and other conditions.
\end{abstract}




\section{Patients and Methods}

Four groups of patients were studied: (1) Eighteen patients who had clinically definite Crohn's disease, including nine with histological confirmation of the diagnosis; five patients in this group were receiving corticosteroid therapy. (2) Four patients in whom the diagnosis of Crohn's disease was considered probable; one was receiving corticosteroids. (3) Nine patients who had clinically definite ulcerative colitis; two were receiving corticosteroids. And (4) nine controls: eight with a variety of other diseases-namely, pyelonephritis, renal calculi, focal glomerulonephritis, thyrotoxicosis, pilonidal sinus, cholelithiasis, alocholic cirrhosis, and post-gastrectomy syndrome-and one with iron-deficiency anaemia with normal intestinal contrast studies. None of these patients were receiving corticosteroids.

Leucocyte Migration Test.-The technique described by Soborg and Bendixen (1967) was followed, but with minor modifications. Peripheral leucocytes concentrated in capillary tubes were incubated for at least 18 hours in culture chambers to which had been added the suspensions under study. Preliminary trials in which these suspensions were added in concentration of $0.001,0.0025,0.01,0.02,0.04$, and 0.1 by volume of the final culture medium established that the last of these gave the most consistent inhibition of leucocytes by sarcoid spleen suspension, and this concentration $(0 \cdot 1)$ of both sarcoid and normal spleen suspensions was therefore used for the present study. With few exceptions, tests with normal and sarcoid spleen suspensions were carried out simultaneously. Leucocyte migration was measured by weighing pieces of paper corresponding in area to the projected images of the migration zones. Results were expressed as a "migration index":

Migration index $=\frac{\text { mean migration in chambers containing suspension }}{\text { mean migration in chambers without suspension }}$

In 16 experiments the observer was unaware of the diagnosis of the patients studied or of the precise nature of the suspensions added to the culture chambers. The results of these 16 experiments are described as "blind" readings, the remainder as "non-blind."

The Suspensions.-The sarcoid spleen used was a ChaseSiltzbach type 3 Kveim suspension prepared from spleen K19.

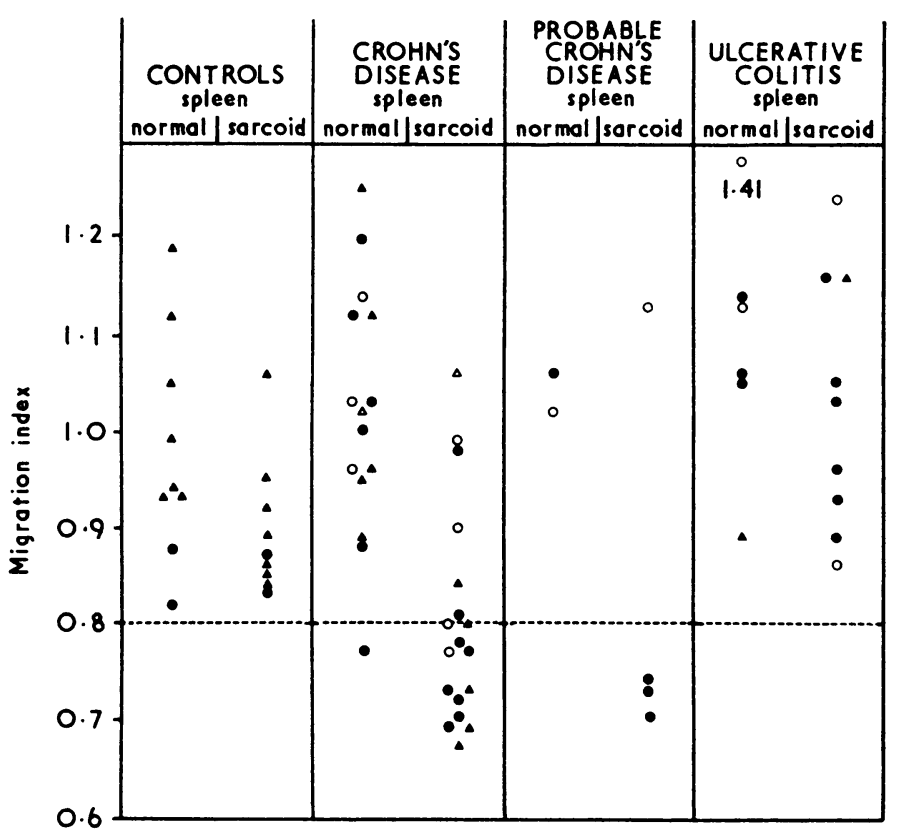

Leucocyte migration in the presence of sarcoid and normal spleen suspensions. Blind: corticosteroids $\triangle$; no corticosteroids $\Delta$. Non-blind: corticosteroids $\mathbf{O}$; no corticosteroids
The normal spleen suspension was a Chase-Siltzbach type 1 Kveim suspension prepared from a normal spleen (KNS). Both suspensions were prepared phenol free.

\section{Results}

Comparative migration of leucocytes in the presence of sarcoid and normal spleen suspensions for patients in each of the four groups is shown in the Chart. Twelve out of 18 patients with clinically definite or histologically confirmed Crohn's disease and three out of four patients with probable Crohn's disease had a migration index of 0.8 or less with sarcoid spleen suspension. No such inhibition occurred with this suspension in either of the two remaining groups (ulcerative colitis patients and controls). A tendency to enhancement of migration was seen in the readings for patients with ulcerative colitis when compared with the readings for the control group $(P<0.05)$. There was no appreciable difference between the various groups in respect of leucocyte migration in the presence of normal spleen suspension. Among those with definite and probable Crohn's disease the range of readings for leucocyte migration with sarcoid spleen suspension was significantly higher for the six patients who were receiving corticosteroids than for those who remained untreated $(P<0.02)$. The "blind" readings show distributions which correspond well with those of "non-blind" readings.

\section{Discussion}

Of the 18 patients with definite, clinically active Crohn's disease, $12(67 \%)$ were clearly distinguishable from a control group with other miscellaneous diseases in yielding leucocytes which showed pronounced inhibition of migration following culture with sarcoid spleen suspension. A smaller group of patients in whom Crohn's disease was the most probable diagnosis gave a similar pattern. The only other subjects to have shown comparable inhibition were two patients with sarcoidosis (not included in this study) whose migration indices of 0.78 and 0.8 accord with the finding of Hardt and Wanstrup (1969) that such patients gave a migration index of 0.8 or less, while values for normal subjects lay in the region of unity and those for tuberculous patients occupied an intermediate position. It is noteworthy that Hardt and Wanstrup (1969) used a sarcoid suspension prepared from another spleen (Hurley).

Leucocytes from patients with Crohn's disease who were receiving corticosteroid treatment showed less inhibition of migration than those from patients not on corticosteroids, and this difference attained statistical significance. Apparent disease activity was no less marked in the treated than in the untreated group, and it is therefore possible that this finding is attributable to a direct effect of corticosteroids on the reactivity of the leucocyte population.

In recent years the differential diagnosis between ulcerative colitis and Crohn's disease of the large bowel has been facilitated by increasing recognition of certain clinical, radiological, and pathological features which may be helpful in distinguishing between them (Lockhart-Mummery and Morson, 1964; Marshak and Lindner, 1966). There remains, however, good evidence that the two diseases may share common epidemiological (Monk, Mendeloff, Siegel, and Lilienfeld, 1969), familial (Van der Reis, 1969), and immunological (Shorter, Cardoza, ReMine, Spencer, and Huizenga, 1970) facets; and lately a new emphasis has been placed on the degree to which features generally recognized as characteristic of one condition may appear in the other, blurring the distinction between them and thus increasing the proportion of cases to which neither diagnosis may be confidently applied (Schachter, Goldstein, Rappaport, Fennessy, and Kirsner, 1970; Glotzer et al., 1970). It is, therefore, of more than theoretical interest that in the present 
investigation sarcoid spleen suspension has induced an even greater contrast in patterns of leucocyte migration between a group of patients with Crohn's disease and a group with ulcerative colitis than between the former and a miscellaneous group posing no problem in differential diagnosis.

Only one out of 17 untreated patients with definite or probable Crohn's disease showed leucocyte migration within the range found for nine patients with ulcerative colitis. That the two diseases may react differently in migration inhibition systems has already been shown by Bendixen (1967), who found that inhibition of leucocyte migration in the presence of mucosal extracts occurred in ulcerative colitis but not in Crohn's disease, and by Dykes (1970), who, using a closely related technique, has shown that this pattern is reversed if faecal extracts or small-bowel contents are substituted as "antigen."

In order to gain acceptance as a reliable complementary test in the diagnosis of Crohn's disease the measurement of leucocyte migration in the presence of sarcoid spleen suspension must first be shown to give comparable results with different batches of suspension prepared from both K19 and other sarcoid spleens. The mechanism of migration inhibition in this system is the object of current investigation, and in this context it is of interest that the results of a concurrent study in which the same strict criteria of our earlier reports were used (Mitchell et al., 1969, 1970) have thus far shown positive Kveim tests with a carefully validated test suspension (K12) in 8 out of 34 patients with a clinical diagnosis of ulcerative colitis and in 5 out of 12 with coeliac disease, and that closely similar results have been obtained following simultaneous Kveim tests among the same patients with another widely used (Hurley) test suspension (Mitchell, Cannon, Dyer, Hinson, and Willoughby, to be published). It is, therefore, already necessary to consider the possibility that the cutaneous and in-vitro responses to sarcoid spleen suspensions may be partially or wholly distinct.
We are grateful to Dr. A. M. Dawson and to Professor D. A. Willoughby for their constant help and encouragement, and to the former also for making available most of the patients studied. The remainder participated by kind permission of other physicians and surgeons on the staff of St. Bartholomew's Hospital. We thank Dr. C. M. Patricia Bradstreet, Director, Standards Laboratory for Serological Reagents, Central Public Health Laboratory, London, for preparations of the sarcoid and normal spleen suspensions, and Drs. W. Fox, R. J. W. Rees, and I. Sutherland for their comments and advice.

J. M. T. Willoughby, to whom requests for reprints should be addressed at St. Bartholomew's Hospital, London E.C.1, is supported by a grant from the Medical Research Council.

\section{References}

Bendixen, G. (1967). Scandinavian fournal of Gastroenterology, 2, 214. Bendixen, G., and Soborg, M. (1969). Danish Medical Bulletin, 16, 1. Dykes, P. W. (1970). Proceedings of the Royal Society of Medicine, 63, 906. Glotzer, D. J., et al. (1970). New England fournal of Medicine, 282, 582. Hardt, F., and Wanstrup, J. (1969). Acta Pathologica et Microbiologica Scandinavica, 76, 493.

Hart, P. D'A., and Rees, R. J. W. (1967). British Medical Bulletin, 23, 80. Lockhart-Mummery, H. E. and Morson, B. C. (1964). Gut, 5, 493.

Marshak, R. H., and Lindner, A. E. (1966). Fournal of the Mount Sinai Hospital, 33, 444

Mitchell, D. N., Cannon, P., Dyer, N. H., Hinson, K. F. W., and Willoughby, J. M. T. (1969). Lancet, 2, 571 .

Mitchell, D. N., Cannon, P., Dyer, N. H., Hinson, K. F. W., and Willoughby, J. M. T. (1970). Lancet, 2, 496.

Monk, M., Mendeloff, A. I., Siegel, C. I., and Lilienfeld, A. (1969). Gastroenterology, 56, 847 .

Schachter, H., Goldstein, M. J., Rappaport, H., Fennessy, J. J., and Kirsner, J. B. (1970). Annals of Internal Medicine, 72, 841 .

Shorter, R. G., Cardoza, M. R., ReMine, S. G., Spencer, R. J., and Huizenga, K. A. (1970). Gastroenterology, 58, 692 .

Siltzbach, L. E. (1967). In La Sarcoidose Rapports de la IVe Conférence internationale, ed. J. Turiaf and J. Chabot, p. 201. Paris, Masson.

Soborg, M., and Bendixen, G. (1967). Acta Medica Scandinavica, 181, 247. Van der Reis, L. (1969). American fournal of Gastroenterology, 52, 56.

\section{PRELIMINARY COMMUNICATIONS}

\section{Mechanisms for Eosinophilic and Neutrophilic Leucocytoses}

\author{
R. S. WALLS, A. BASTEN, E. LEUCHARS, \\ A. J. S. DAVIES.
}

British Medical fournal, 1971, 3, 157-159

\section{Summary}

Thymus-deprived mice are unable to react with eosinophilia to an appropriate stimulus, but their ability to mount a neutrophil leucocytosis in response to pyogenic infection is unimpaired. It appears that thymusprocessed lymphocytes are required for induction of eosinophil but not of neutrophil leucocytosis.

\footnotetext{
Nuffield Department of Clinical Medicine, Radcliffe Infirmary, United Oxford Hospitals, Oxford

R. S. WALLS, M.B., F.C.P.(s.A.), C. J. Adams and J. W. Duncan Baxter Fellow

A. BASTEN, M.D., D.PHIL., Nuffield Dominions Trust Fellow

Department of Immunobiology, Chester Beatty Research Institute, Institute of Cancer Research, Royal Cancer Hospital, London SW3 6JB

E. LEUCHARS, M.A., PH.D., Lecturer

A. J. S. DAVIES, B.SC., PH.D., Senior Lecturer
}

\begin{abstract}
Introduction
Though eosinophilia is frequent in such conditions as parasitic infections and allergy the function of these cells and the steps leading to their increased production in man have not been established. However, in rats given Trichinella spiralis larvae eosinophilia has been shown to depend on a population of competent lymphocytes and to have some characteristics of an immune reaction (Basten and Beeson, 1970). The response is quantitated by measuring the blood eosinophil level, which has proved to be an accurate indicator of increased production of eosinophils in bone marrow (Basten et al., 1970; Spry, 1970). We decided to determine whether this eosinophil response to trichinella larvae is thymus-dependent in mice and whether a neutrophil leucocytosis induced by pyogenic infection is similarly regulated.
\end{abstract}

\section{Materials and Methods}

Sixty $\mathrm{CBA} / \mathrm{H}$ male mice were thymectomized at 8 weeks of age. Two weeks later they were subjected to 850 rads total body irradiation from a $220-\mathrm{kV} x$-ray machine. Within three hours $5 \times 10^{6}$ syngenic bone marrow cells were injected intravenously. Some of the mice were then grafted with a single lobe of CBA/H.T6T6 neonatal thymus beneath the capsule of the left kidney. About 30 animals prepared in this way are referred to as "reconstituted" mice. A further 30 mice not given thymus grafts are called "deprived." Thirty normal CBA/H male mice were also included in the experiment. In a few instances irradiated mice were left with the thymus in situ. Such animals 